\title{
W POSZUKIWANIU ZANIECZYSZCZEŃ CHEMICZNYCH WODY
}

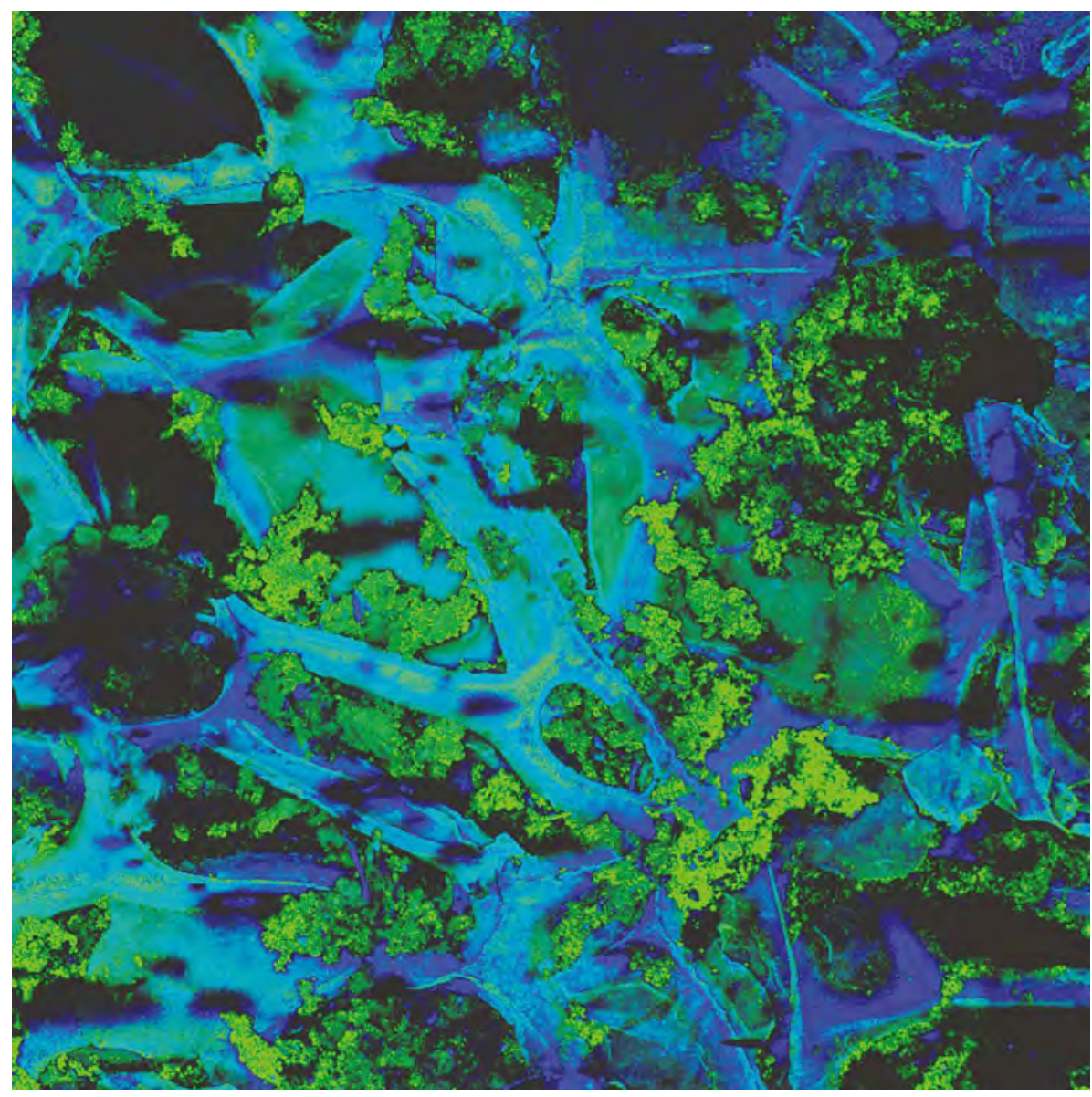

Element biologiczny ABTOW zwizualizowany przy pomocy konfokalnego laserowego mikroskopu skaningowego (CLSM). Mikroorganizmy zaznaczono na zielono, a gąbkę poliuretanową - na niebiesko / fot. Tytus Bernaś, Andrzej Woźnica

Człowiek ma ogromny wpływ na jakość wody w środowisku - zarówno poprzez wprowadzanie do niej różnorodnych substancji chemicznych, jak i przez ingerencję w jej naturalny obieg. Źródłami kontaminacji są nie tylko urbanizacja, górnictwo, nadmierne i czasem niewłaściwe korzystanie z różnego rodzaju środków chemicznych - głównie w rolnictwie - ale przede wszystkim przemysł. 
Wzrost liczby ludności na danym obszarze powoduje zwiększone zużycie środków ochrony osobistej i farmaceutyków, sektor transportu jest źródłem metali ciężkich i węglowodorów ropopochodnych, $\mathrm{w}$ tym wielopierścieniowych węglowodorów aromatycznych (WWA). Istotnymi, tak zwanymi punktowymi źródłami zanieczyszczeń, są wysypiska śmieci, z których do wód gruntowych przedostają się różnorodne substancje chemiczne, a nawet substancje radioaktywne. W wyniku działalności rolniczej do środowiska uwalnianych jest wiele substancji biobójczych, często zawierających znaczne ilości metali ciężkich, szczególnie kadmu, cynku i miedzi, jak również leków weterynaryjnych. Zupełnie odrębnym zagadnieniem są substancje chemiczne stosowane w przemyśle.

Istotnym problemem stają się farmaceutyki, które dostają się do wody trzema drogami: przez ścieki komunalne, ścieki z zakładów produkcyjnych, a także z ośrodków hodowli zwierząt gospodarskich. Wydalane antybiotyki niestety wciąż zawierają aktywną substancję.

- Związki ksenobiotyczne, czyli obce, o strukturze chemicznej niewystępującej w przyrodzie, do których należy znakomita większość farmaceutyków, często nie ulegają pełnemu rozkładowi mikrobiologicznemu, a jedynie częściowemu przekształceniu, czyli biotransformacji. Taką sytuację obserwuje się w oczyszczalniach ścieków, w których mikroorganizmy w postaci osadu czynnego nie dysponują odpowiednią maszynerią enzymatyczną zdolną do pełnej mineralizacji tego typu substancji - wyjaśnia dr Agnieszka Nowak z Instytutu Biologii, Biotechnologii i Ochrony Środowiska Uniwersytetu Śląskiego.

Tak ogromna różnorodność substancji mogących stanowić zagrożenie dla funkcjonowania ekosystemów wymagała wprowadzenia regulacji prawnych wymuszających kontrolę stężeń związków, które zostały uznane za toksyczne, niebezpieczne czy potencjalnie szkodliwe. W 2001 roku decyzją Parlamentu Europejskiego i Rady ustanowiono listę 33 substancji priorytetowych i 8 innych zanieczyszczeń. Wprowadzanie tych związków do środowiska powinno być stopniowo redukowane, a w przypadku priorytetowych substancji niebezpiecznych - całkowicie zakazane. Na pierwszej liście substancji priorytetowych znalazły się węglowodory wchodzące w skład insektycydów i herbicydów, inne węglowodory zarówno alifatyczne, jak i aromatyczne, metale ciężkie i ich związki (głównie kadmu, niklu, ołowiu i rtęci) oraz związki metaloorganiczne. W dyrektywie Parlamentu Europejskiego i Rady z 2013 roku założono utworzenie i stałe uzupełnianie tak zwanej listy obserwacyjnej (Watch List). Na liście tej po raz pierwszy znalazły się substancje farmaceutyczne jak 17 a-etynyloestradiol (EE2), $17 \beta$-estradiol (E2), antybiotyki makrolidowe (erytromycyna, klarytromycyna, azytromycyna) oraz diklofenak. Istotny jest fakt, że nie zakwestionowano wartości medycznej tych substancji, ale wykazano, że obecność tych związków w środowisku wodnym może działać szkodliwie na zdrowie ryb, ograniczać ich reprodukcję oraz działać szkodliwie na inne organizmy.

- Już w latach 50. XX wieku badania ekosystemów wodnych pozwoliły zaobserwować procesy, w wyniku których następuje wzrost stężenia substancji toksycznych w organizmach zajmujących wyższy poziom troficzny, czyli tak zwaną biomagnifikację. Jako szczególnie narażone wymienia się takie gatunki ryb, jak tuńczyk czy łosoś, następnie ptaki jedzące ryby, ssaki morskie (foki i delfiny) i ludzi. Jako jedne z najgroźniejszych następstw tego zjawiska opisuje się zaburzenia hormonalne, zakłócenia funkcji reprodukcyjnych, endokrynologicznych i aktywności steroidogennej. Badania w wielu krajach Europy wykazały również wiele zaburzeń $\mathrm{w}$ funkcjonowaniu i rozrodzie ryb słodkowodnych - dodaje dr Agnieszka Nowak.

Na terenie całej Unii Europejskiej w wodach powierzchniowych stwierdza się występowanie niektórych środków przeciwbólowych, przeciwdrobnoustrojowych, antydepresyjnych, antykoncepcyjnych i przeciwpasożytniczych.

- Niepokojący jest fakt, że leki, takie jak estrogeny, diklofenak czy naproksen, są wykrywane również w wodzie pitnej. W Polsce też stwierdzono obecność farmaceutyków w wodach powierzchniowych i w wodzie pitnej, np. naproksenu i bezafibratu w Warcie czy diklofenaku w Odrze. Stężenia tych farmaceutyków wynosiły kilkaset nanogramów. W wodzie pitnej wykryto obecność niesteroidowych leków przeciwzapalnych w stężeniu kilku nanogramów - wyjaśnia badaczka.

Jednym z rozwiązań problemu, jakim jest pojawianie się substancji ksenobiotycznych w wodach, jest zwiększenie wydajności i intensyfikacja ich biologicznego rozkłładu w oczyszczalniach ścieków. Można to osiągnąć poprzez wprowadzenie wyselekcjonowanych szczepów mikroorganizmów zdolnych do biodegradacji określonych zanieczyszczeń. Niestety na razie badania te prowadzone są głównie w skali laboratoryjnej.

Sposobów na detekcję zanieczyszczeń w wodzie jest wiele. Również badacze Uniwersytetu Śląskiego postanowili dołożyć cegiełkę do walki z zanieczyszczeniem wody. Automatyczny Biodetektor Toksyczności Ogólnej Wody (ABTOW) to zautomatyzowany biologiczny system detekcji łączący właściwości wybranych mikroorganizmów - bakterii nitryfikacyjnych z czujnikami elektrochemicznymi. Powstał dzięki pracy interdyscyplinarnego zespołu badawczego Uniwersytetu Śląskiego pod kierownictwem dr. hab. Andrzeja Woźnicy, prof. UŚ. Badania nad ABTOW są prowadzone od ponad dekady. Urządzenie daje możliwość szybkiego wykrycia zanieczyszczeń, które mogą znajdować się w wodzie. Może być instalowane przy ujęciu wody surowej lub w ciągu technologicznym odpowiadającym za uzdatnianie wody. Reaguje na obecność metali ciężkich, substancji priorytetowych, ale również bardzo powszechnie stosowanych w przemyśle fenoli.

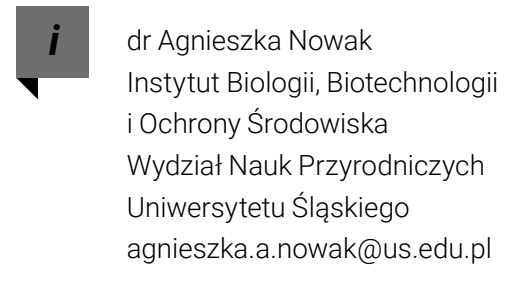

